\title{
THE EFFECTS OF DIFFERENT POLLEN TRAPPING PERIODS AND INTERVALS ON AMOUNT OF POLLEN AND NUMBER OF POLLEN COLLECTING WORKER HONEYBEES (APIS MELLIFERA L.)
}

\author{
Balarısı (Apis Mellifera L.) Kolonilerinde Polen Tuzağı Takmanın ve Süresinin Polen \\ Toplayan İşçi Arı Sayısına ve Polen Miktarı Üzerine Etkileri \\ (Genişletilmiş Türkçe Özet Makalenin Sonunda Verilmiştir)
}

\author{
Ethem AKYOL ${ }^{1}$, Adnan UNALAN ${ }^{2}$
}

\author{
${ }^{1}$ University of Ömer Halisdemir, Faculty of Agricultural Sciences and Technologies, Department of Animal \\ Production and Technologies, 51240 Nigde, Turkey, e-mail: eakyol@ohu.edu.tr \\ ${ }^{2}$ University of Ömer Halisdemir, Faculty of Economics and Administrative Sciences, Department of Business, \\ 51240 Nigde, Turkey, e-mail: unalanadnan@gmail.com \\ Geliş Tarihi: 26.09.2016 Kabul Tarihi: 10.11.2016
}

\begin{abstract}
This research was carried out to determine the effects of pollen trapping schemes on pollen gathering activity of worker honeybees in the Apiary of Omer Halisdemir University. In total 20 honeybee (Apis mellifera anatoliaca) colonies were used and divided randomly into four groups after they were equalized with respect to strength, brood area, food stocks and weight. Throughout the experiment, pollen traps were used every day in the first group of colonies, equipped with every second day in the second group of colonies in intervals of three days in the third group of colonies while the fourth group of colonies had no traps as used the control group. Throughout the experiment, pollen collecting bees from all colonies were monitored daily at five different times at the entrance of the hives for a period of ten minutes per time point. The first group gathered in average the maximum amount of pollen as to be $75.20 \pm 4.08 \mathrm{~g} /$ day/colony, the second and the third groups gathered in average $40.35 \pm 1.41$ and $37.23 \pm 1.54 \mathrm{~g} /$ day/colony respectively. Significant differences were detected between the groups in respect of both the number of pollen collectors and amount of pollen. It was shown that colonies in all groups gathered the maximum amount of pollen at 7:00 a.m. (165.81 \pm 15.8 number/ten minutes/colony) and at 9:00 a.m. (177.39 \pm 20.06 number/ten minutes/colony) and the least pollen at 15:00 p.m. (19.52士1.68 number/ten minutes/colony).
\end{abstract}

Keywords: Honeybee, Pollen, Pollen trap, Trapping time.

\section{ÖZ}

Bu çalışma balarısı(Apis mellifera anatoliaca) kolonilerine değişik aralıklarla polen tuzağı takmanın işçi arıların polen toplama aktiviteleri ve koloninin polen verimine etkisini belirlemek amacıyla yürütülmüştür. Günlük ortalama en fazla polen'i $(75.20 \pm 9.12 \mathrm{gr} / \mathrm{gün} / \mathrm{koloni})$ her gün tuzak takılı olan I. Grup koloniler toplarken, bir gün ara ile tuzak takılan II. Grup $(40.35 \pm 3.15 \mathrm{gr} / \mathrm{gün} / \mathrm{koloni})$ ve üç gün ara ile tuzak takılan III. Grup $(37.23 \pm 3.45 \mathrm{gr} / \mathrm{gün} / \mathrm{koloni})$ koloniler ise daha az polen toplamışlar ve aynı istatistiki grupta yer almışlardır. Günün değişik saatlerinde polen yükü ile gelen arı sayıları bakımından hem gruplar hem de saatler arasındaki farklılık istatistiki olarak önemli bulunmuştur $(P<0.01)$. Tüm gruplardaki koloniler en fazla poleni saat $7: 00 \quad(165.81 \pm 15.8$ adet/10 dakika/koloni) ve 9:00(177.39 \pm 20.06 adet/10 dakika/koloni) saatlerinde toplamışlar, en az poleni ise 15:00(19.52 1.68 adet/10 dakika/koloni) saatlerinde topladıkları belirlenmiştir.

Anahtar Sözcükler: Bal arısı, Polen, Polen tuzağı, Tuzaklama zamanı 


\section{ARAŞTIRMA MAKALESI / RESEARCH ARTICLE}

\section{INTRODUCTION}

Pollen and nectar are two key nutrients to continue the life activity of the honeybee colony (Akyol and Camcı, 1998). The nectar is necessary for carbohydrate needs of honeybees, while pollen is necessary for protein, fat, minerals and vitamins needs of them. Carbohydrate and water are sufficient for adult member of the honeybee colony but protein, lipids, minerals and vitamins are essential to growth and development of larvae and pupa (Standifer et al., 1977; Pernal and Currie, 2001). Nursing activity plays an important role to the development of honeybee colony. The royal jelly, which is secreted by the mandibular glands of young worker bees and has rich-protein content, is essential for the development of larvae. Young workers have to consume plenty of pollen to secrete royal jelly. Pollen is not only important to the secretion of royal jelly but also essential to complete the development of certain body tissues of young bees (Hrassnigg and Crailsheim, 1998; Zerbo and Moraes, 2001). Worker bees store the surplus pollen near the brood area during the rich pollen season. The stored pollen is used to meet the pollen needs of the colony during non-flowering season or when the worker bees don't forage. A strong honeybee colony can gather more than 45 $\mathrm{kg}$ pollen in one year (Standifer, 2003). Collected pollens of all the plants are not of the same quality. A single kind of pollen is not usually sufficient to feed the brood and adult. Protein content of pollen ranges from $10 \%$ to $36 \%$.

The aim of this research was to determine the effects of the different periods of the pollen trapping on the amount of pollen collected and the activity of pollen collecting worker bees during different times of the day.

\section{MATERIALS AND METHODS}

Anadolu honeybees (Apis mellifera anatoliaca) and standard Langstrooth hives were used in this research. Queens of the colonies were reared at the same time and the same condition from larvae taken from the same breeding colony in the Apiary of Nigde University.

In total twenty colonies were used, which had naturally-mated queens reared from larvae taken from the same breeding colony in the same season. At the beginning of the study, the colonies were equalized according to the brood area, frame with bees and nutrient stock and were randomly distributed into four groups, each consisted of five colonies.

The treatment groups were arranged as follows:

I. Group: Pollen traps were placed daily

II. Group: Pollen traps were placed every other second day

III. Group: Pollen traps were placed for three-day periods with three days intervals

IV. Group: No pollen traps were placed (control group)

Portable wooden pollen traps with perforated plastic plates with dimensions of $29.2 \mathrm{~cm} \times 8.5 \mathrm{~cm} \times 8.5$ $\mathrm{cm}$ were used to collect pollens. The plastic plates were perforated into circular holes of diameter of $4.8 \mathrm{~mm}$ that allowed bees without pollens to pass through easily. The pollens were accumulated in the pollen reservoirs below the traps.

The research was started on May $15^{\text {th }}$, a season in which pollen flow and brood activities begins to ascend and the daily pollen quantities collected by the experimental colonies was accessed.

The traps were in use between the hours 05:00 a.m. and 15:30 p.m. Additionally the number of bees that coming with pollen from 07:00 a.m. until to $15: 10$ p.m. was determined for a duration of 10 minutes at 5 different times per day for the days the traps were on in each group. Then the amounts of pollens in the traps were determined by weighing the yield at the end of each day (Alataş et al., 1997).

Pollen yield and pollen gathering activity of the experimental groups were analysed with One-way ANOVA (Analysis of Variance) test in SPSS packet program and Duncan multiple comparison test was applied to compare the average pollen yields of groups.

\section{RESULTS}

The average numbers of ( $\pm S E$ ) the worker bees returned to the hives with pollen at different times of each day are given in Table 1 and daily average pollen yields of the 4 different experimental groups are given in Table 2. The first, the second and the third groups of colonies gathered at an average of $75.20 \pm 4.08, \quad 40.35 \pm 1.41$ and $37.23 \pm 1.54 \mathrm{~g}$ pollen/day/colony respectively. The first group of 


\section{ARAŞTIRMA MAKALESI / RESEARCH ARTICLE}

colonies gathered the maximum amount of pollen daily. There were statistically significant differences among the groups and among the different control times of the day on worker bees coming with pollen
$(P<0.01)$. But, there was no statistically significant differences between the second and third group $(P>0.05)$.

Table 1. Number $( \pm S E)$ of worker bees returned to the hive with pollen load at different times of the day (number/10 minutes)

\begin{tabular}{|c|c|c|c|c|c|c|}
\hline \multirow[b]{2}{*}{ Groups } & \multicolumn{5}{|c|}{ Control Times } & \multirow[b]{2}{*}{$\begin{array}{c}\text { Overall } \\
\text { Mean } \pm \text { SE }\end{array}$} \\
\hline & $\begin{array}{l}\text { 7:00-7:10 } \\
\text { Mean } \pm S E\end{array}$ & $\begin{array}{l}9: 00-9: 10 \\
\text { Mean } \pm \text { SE }\end{array}$ & $\begin{array}{c}11: 00-11: 10 \\
\text { Mean } \pm S E\end{array}$ & $\begin{array}{c}\text { 13:00-13:10 } \\
\text { Mean } \pm S E\end{array}$ & $\begin{array}{c}\text { 15:00-15:10 } \\
\text { Mean } \pm S E\end{array}$ & \\
\hline I. Group & $210.20 \pm 9.01^{\mathrm{a}^{\mathrm{x}}}$ & $219.18 \pm 10.81^{\mathrm{a}}$ & $130.45 \pm 5.61^{\mathrm{a}}$ & $60.45 \pm 2.56^{\mathrm{a}}$ & $28.15 \pm 0.99^{\mathrm{a}}$ & $129.69 \pm 2.90^{\mathrm{a}}$ \\
\hline II. Group & $160.26 \pm 7.70^{\mathrm{b}}$ & $176.28 \pm \pm 9.56^{b}$ & $102.23 \pm \pm 4.57^{b}$ & $42.65 \pm 1.50^{\mathrm{b}}$ & $19.34 \pm 0.64^{b}$ & $100.15 \pm 2.40^{b}$ \\
\hline II. Group & $154.35 \pm 5.96^{b}$ & $168.46 \pm 8.24^{b}$ & $95.53 \pm 3.81^{\mathrm{b}}$ & $39.46 \pm 1.42^{\mathrm{b}}$ & $17.44 \pm 0.84^{\mathrm{b}}$ & $95.05 \pm 2.03^{b}$ \\
\hline IV. Group & $138.43 \pm 5.60^{c}$ & $145.66 \pm 7.27^{\mathrm{c}}$ & $73.48 \pm 2.85^{\mathrm{c}}$ & $33.21 \pm 1.05^{\mathrm{c}}$ & $13.15 \pm 0.54^{c}$ & $80.79 \pm 1.73^{\mathrm{C}}$ \\
\hline
\end{tabular}

Table 2. Average $( \pm S E)$ pollen yields ( $g /$ colony/day) of the groups

\begin{tabular}{lccccc} 
Groups & $\mathbf{n}$ & Min & Max & Mean $\pm S E$ & Days with traps \\
\hline I. Group & 5 & 65 & 90 & $75.20 \pm 4.08^{\mathbf{a}^{\mathrm{a}}}$ & 12 \\
II. Group & 5 & 34 & 55 & $40.35 \pm 1.41^{\mathrm{b}}$ & 6 \\
III. Group & 5 & 31 & 48 & $37.23 \pm 1.54^{\mathrm{b}}$ & 6 \\
IV.Group(Cont) & 5 & - & - & - & - \\
\hline Overall & 20 & 31 & 90 & $50.93 \pm 1.09$ & 24
\end{tabular}

${ }^{*}$ : Different letters indicate the different statistical groups (Duncan, $\mathrm{P}<0.01$ ).

\section{DISCUSSIONS}

In the present study, statistically significant differences were found both among the experimental groups and among the number of the worker bees returning to the hive with pollen load at different times of the day $(P<0.01)$. Interestingly these differences are exactly the same for every time point of recordings.

In all groups, the maximum number of worker bees returned to the colony with pollen was observed at 7:00 a.m. (165.81 \pm 15.8 number/10 minutes) and 9:00 a.m. (177.39 \pm 20.06 number/10 minutes). This number was decreased substantially in the afternoon and observed as $19.52 \pm 1.68$ number/10 minutes at 15:00 p.m.

In this study, the results of pollen gathering activity at different times of the day were not in agreement with the results reported by Erdoğan and Dodoloğlu (2005). This difference may be occurred by different control times of the day. Because, these researchers used just two different times before a.m. hours, but five different times were used to test between 7:00 a.m. and 15:10 p.m. in this research.
The duration of the pollen traps being installed affected the number of pollen collectors significantly. The first group of colonies for which the traps were used daily, they had the maximum amount of pollen collectors. The second group of colonies for which the traps were used every second day and the third group of colonies for which the traps were used in 3 day intervals had less pollen collectors per day than the first group and not statistical difference was found between these two groups. The fourth group of colonies for which no traps were used had less pollen collectors than all other groups. These results showed that the use of both pollen traps affected pollen collection according to the period of trapping.

Daily pollen gathering values of all groups in this research were higher than the results reported by Erdoğan and Dodoloğlu (2005), Korkmaz (1997), Bayram et al. (2004) and Kumova and Korkmaz (2003). The region, year, vegetation, colony strenght and the genetic structure are all probably the obvious reasons for differences.

Keeping pollen traps continuously on a colony is positive for gathering higher amounts of pollen, but 


\section{ARAŞTIRMA MAKALESI / RESEARCH ARTICLE}

it has to be used with caution as brood rearing activities would decrease and the population and productivity of the colonies would be affected negatively if this process is maintained for a long time. For a sustainable apiculture, the authors suggest that a more comprehensive economical analysis of pollen collection schemes as well as of colony productivity should be conducted.

\section{REFERENCES}

Akyol, E. and Camcı, O., 1998. Arıcılığın bitkisel üretimdeki yeri ve önemi. GAP Birinci Tarım Kongresi Bildirileri, Cilt. 2, pp. 1157, Şanlıurfa, Turkey.

Alataş, İ., Yalçın L.í. and Öztürk, A.İ., 1997. Arıcılıkta polen üretiminin koloni gelişimine ve bal verimine etkileri. Journal of Ege Agricultural Research Institute, 7(1), 30-42.

Bayram, A., Akyol, E., Yeninar, H. and Öztürk, C., 2004. Bal arılarında (Apis mellifera L.) polen toplama sürelerinin koloni gelişimi ve bal üretimine etkisi. Uludağ Bee Journal, 4(1), 2934.

Erdoğan, Y. and Dodoloğlu, A., 2005. Bal arılarında (Apis mellifera L.) polen toplama faaliyetlerinin koloni gelişimi ve bal verimi üzerine etkisi. Uludağ Bee Journal, 5(2), 79-84.

Hrassnigg, N.and Crailsheim, K., 1998. The influence of brood on the pollen consumption of worker bees (Apis mellifera L.). Journal of Insect Physiology, 44, 393-404.

Korkmaz, A., 1997. Çukurova bölgesi koşullarında yetiştirilen fazelya (Phecelia tanaceti folia, Bentham) bitkisinin balarısı (Apis mellifera L.) kolonilerinin populasyon gelişimine, nektar ve polen toplama etkinliğine olan etkilerinin araştırılması. Çukurova University, Institute of Science, MSc Thesis, pp. 51, Adana.

Kumova, U. and Korkmaz, A., 2003. Bal arısı (Apis mellifera L.) kolonilerinde nektar akımı öncesi polen üretiminin koloni populasyonuna olan etkilerinin araştırılması. Mellifera, 3(5), 23-29.

Pernal, S.F. and Currie, R.W., 2001. The influence of pollen quality on foraging behavior in honeybees (Apis mellifera L.). Behavioral Ecology and Sociobiology, 51, 53-68.

Standifer, L.N., Moeller, F.E., Kauffeld, N.M., Herbert E.W. and Shimanuki, H., 1977.Supplemental feeding ofhoney bee colonies. United States Department of Agriculture, Agriculture Information Bulletin No. 413, pp. 8.

Standifer, L.N., 2003. Honey bee nutrition supplemental feeding. http://maarec.cas.psu.edu/bkCD/HBBiology/nutri tion-supplements.htm.

Zerbo, A.C. and Moraes, R.L.M.S., 2001. Protein requirements in larvae and adults of scaptotrigona postica (Hymenoptera: Apidia, Meliponinae) midgut proteolytic activity and pollen digestion. Comparative Biochemistry and Physiology Part B, 129, 139-147.

\section{GENIŞLETILMIŞ ÖZET}

$\mathrm{Bu}$ çalışma bal arısı (Apis mellifera anatoliaca) kolonilerine değişik aralıklarla polen tuzağı takmanın işçi arıların polen toplama aktiviteleri ve koloninin polen verimine etkisini belirlemek amacıyla yürütülmüştür. Çalışma Niğde Üniversitesi Ulukışla Meslek Yüksekokulunda toplam 20 adet bal arısı (Apis mellifera anatoliaca) kolonisi üzerinde yürütülmüştür. Çalışmada standart Langstrooth kovanlar kullanılmıştır. Denemeye alınan koloniler uygulamadan önce arılı çerçeve, yavru alanı ve yiyecek bakımından yaklaşık olarak eşitlenmiş ve tesadüfi bir seçimle beşerli gruplara ayrımışlardır. Kontrol grubundaki kolonilere hiç bir uygulama yapılmazken uygulama gruplarından birincisine her gün, ikincisine bir gün ara ile ve üçüncüsüne üç gün ara ile polen tuzakları takılmıştır. Tüm gruplarda polen tuzakları takılmadan önce ve polen tuzakları takılı iken günün farklı saatlerindeon dakikalık periyotlardakovana polen yükü ile gelen işçi arılar sayılarak kayıt edilmiştir. Günlük ortalama en fazla polen'i $(75.20 \pm 9.12 \mathrm{gr} / \mathrm{gün} / \mathrm{koloni})$ sürekli tuzak takılı olan I. grup koloniler toplarken, II. Grup $(40.35 \pm 3.15 \mathrm{gr} / \mathrm{gün} / \mathrm{koloni})$ ve III. Grup $(37.23 \pm 3.45$ $\mathrm{gr} / \mathrm{gün} / \mathrm{koloni}$ ) koloniler ise daha az polen toplamışlar ve aynı istatistiki grupta yer almışlardır. Günün değişik saatlerinde polen yükü ile gelen arı sayıları bakımından hem gruplar hem de saatler arasındaki farklılık istatistiki olarak önemli bulunmuştur $(P<0.01)$. Tüm gruplardaki koloniler en fazla poleni saat $7^{: 00} \quad(165.81 \pm 15.8$ adet/10 dakika/koloni) ve $9^{: 00}(177.39 \pm 20.06$ adet/10 dakika/koloni) saatlerinde toplamışlar, en az poleni ise $15^{: 00} \quad(19.52 \pm 1.68$ adet $/ 10$ dakika/koloni) saatlerinde topladıkları belirlenmiştir. 